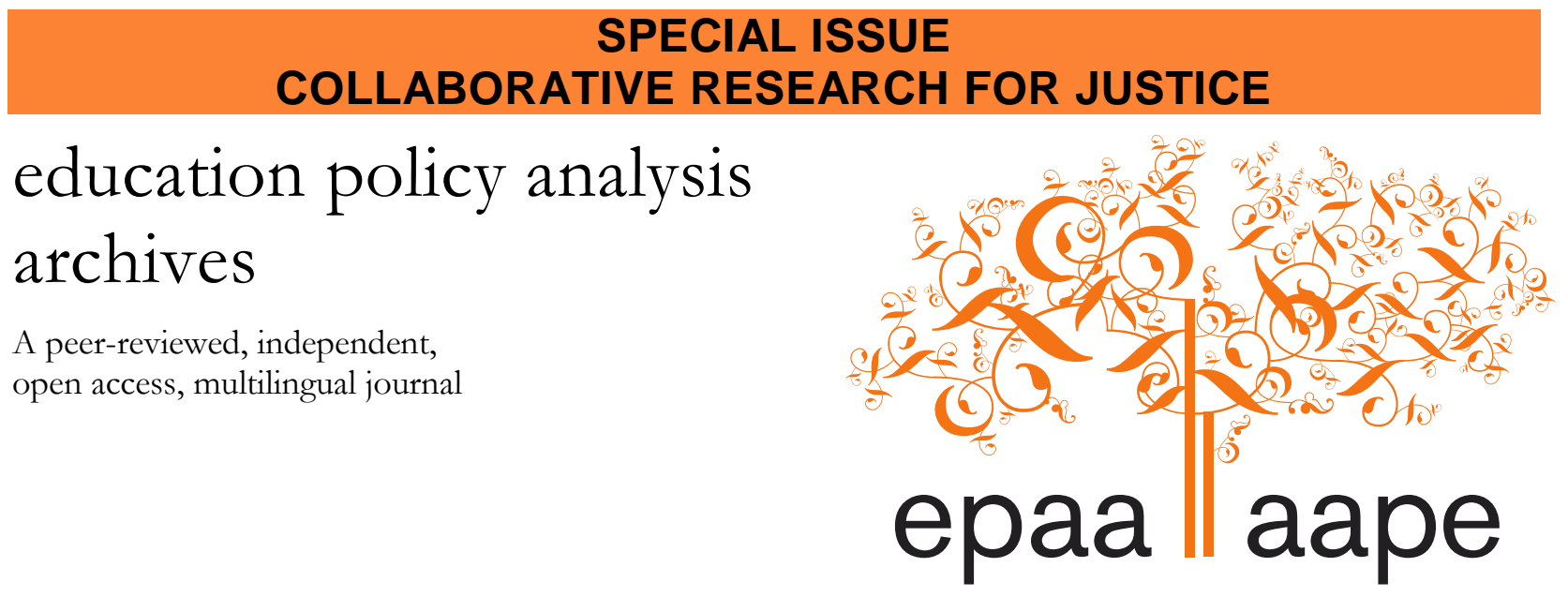

Arizona State University

Volume 27 Number 53

May 20, 2019

ISSN 1068-2341

\title{
Collaborative Research and Multi-Issue Movement Building for Educational Justice: Reflections on the Urban Research Based Action Network (URBAN)
}

\author{
Mark R. Warren \\ University of Massachusetts Boston \\ \& \\ Ronald David Glass \\ University of California, Santa Cruz \\ United States
}

Citation: Warren, M. R., \& Glass, R. D. (2019). Collaborative research and multi-issue movement building for educational justice: Reflections on the Urban Research Based Action Network (URBAN). Education Policy Analysis Archives, 27(53). http://dx.doi.org/10.14507/epaa.27.4445 This article is part of the special issue, Collaborative Research for Justice and Multi-Issue Movement Building, guest edited by Ronald D. Glass \& Mark R. Warren.

\begin{abstract}
Two long-time scholar-activists reflect on a distinctive approach to research that they call collaborative research for justice, research that is conducted with community leaders and education activists to advance equity and social justice. They argue that by linking research directly with action this kind of research has the power to speak directly to the current crises not only in education, but also in the other institutions of civil society. Drawing on decades of experience in public research universities, local community based organizations, inter/national disciplinary research organizations, and distributed informal networks of engaged scholars, social justice activists, and community leaders, they reflect
\end{abstract}


specifically on the more recent formation of the Urban Research Based Action Network (URBAN), a national network of people enacting a variety of forms of collaborative research for justice, now with more than 1500 members. They outline lessons that might contribute to building the multi-issue movement for educational justice that they believe is required to transform public schools to make them serve the needs of the most disadvantaged, aggrieved, and inequitably treated communities. In its short history URBAN has already impacted the academy through the gatherings and meetings it has hosted as well as through a rigorous publishing agenda, including a special issue of EPAA in which this article appears.

Keywords: action research; collaborative research; educational justice

\section{Investigación colaborativa y construcción de movimiento multi-cuestión para la justicia educativa: Reflexiones sobre la Urban Research Based Action Network (URBAN)}

Resumen: Dos académicos-activistas reflexionan sobre un enfoque distinto a la investigación que llaman investigación colaborativa para la justicia, investigación que se dirige con líderes comunitarios y activistas de la educación para promover la equidad y la justicia social. Los autores argumentan que al vincular la investigación directamente a la acción, ese tipo de investigación tiene el poder de hablar directamente a las crisis actuales, no sólo en la educación, sino también en las otras instituciones de la sociedad civil. Con base en décadas de experiencia, reflejan específicamente la formación más reciente de la Urban Research Based Action Network (URBAN), una red nacional de personas que promueven diversas formas de investigación colaborativa para la justicia, ahora con más de 1500 miembros. Describen lecciones que pueden contribuir a la construcción de un movimiento por la justicia educativa, que creen necesario para transformar las escuelas públicas y ayudarlas a satisfacer las necesidades de las comunidades más desfavorecidas, perjudicadas e injustamente tratadas. En su corta historia, el URBAN ya impactó la academia a través de los encuentros y reuniones que organizó, así como por medio de una agenda editorial rigurosa.

Palabras clave: investigación-acción; investigación colaborativa; justicia educativa

\section{Pesquisa colaborativa e construção de movimento multi-questão para a justiça educacional: Reflexões sobre a Urban Research Based Action Network (URBAN)}

Resumo: Dois acadêmicos-ativistas refletem sobre uma abordagem distinta à pesquisa que chamam de pesquisa colaborativa para a justiça, pesquisa que é conduzida com líderes comunitários e ativistas da educação para promover a equidade e a justiça social. Eles argumentam que ao vincular a pesquisa diretamente à ação, esse tipo de pesquisa tem o poder de falar diretamente às crises atuais, não apenas na educação, mas também nas outras instituições da sociedade civil. Com base em décadas de experiência, eles refletem especificamente a formação mais recente da Urban Research Based Action Network (URBAN), uma rede nacional de pessoas que promovem diversas formas de pesquisa colaborativa para a justiça, agora com mais de 1500 membros. Eles descrevem lições que podem contribuir para a construção de um movimento pela justiça educacional, que eles acreditam ser necessário para transformar as escolas públicas e ajudá-las a atender às necessidades das comunidades mais desfavorecidas, prejudicadas e injustamente tratadas. Em sua curta história, o URBAN já impactou a academia por meio dos encontros e reuniões que organizou, bem como por meio de uma agenda editorial rigorosa. 
Palavras-chave: pesquisa-ação; pesquisa colaborativa; justiça educacional

\section{Collaborative Research and Multi-Issue Movement Building for Educational Justice: Reflections on the Urban Research Based Action Network (URBAN)}

As two long-time scholar-activists, we offer these reflections on a distinctive approach to research that we are calling collaborative research for justice. By collaborative research for justice, we mean research that is conducted with community leaders and education activists to advance equity and social justice. By linking research directly with action, we believe this kind of research has the power to speak directly to the current crises not only in education, but also in the other institutions of civil society. Between us we have decades of experience with this kind of research and the struggle to build institutional space for it, within our own public research universities and local community based organizations, and more broadly, in our geographic regions, inter/national disciplinary research organizations, and distributed informal networks of engaged scholars, social justice activists, and community leaders. Here we reflect specifically on the more recent formation of the Urban Research Based Action Network (URBAN), a national network of people enacting a variety of forms of collaborative research for justice, now with more than 1500 members, and the lessons that we have learned that might contribute to building the kind of multi-issue movement for educational justice that we believe is required to transform public schools to make them serve the needs of our most disadvantaged, aggrieved, and inequitably treated communities. In its short history URBAN has already impacted the academy through the gatherings and meetings it has hosted as well as through a rigorous publishing agenda, including the special issue of EPAA/AAPE in which this article appears.

URBAN owes its origin to friends of City University of New York Graduate Center Political Science Professor Marilyn Gittell, who wanted to honor her passing in 2010 by refusing to let her powerful energy and impact in life pass away along with her physical presence. Marilyn was an activist scholar known for her fierce advocacy for public school reform and community control. She supported urban communities as they organized for their rights and mentored a new generation of scholars committed to producing research to advance racial, gender and educational justice. Sara Miller McCune, a former student of Marilyn's and the founder of SAGE Publications, asked Dayna Cunningham to help memorialize Marilyn, and Dayna, Director of MIT's CoLab, and at the center of Marilyn's circle of students and friends, immediately thought of creating a living memorial in Marilyn's spirit. With financial support from SAGE and with a vision of creating a network of scholars and activists committed to addressing inequalities in all its forms and finding new solutions to the pressing problems of racial inequities and social injustices in urban communities, Dayna seized the opportunity.

Dayna reached out to some of her friends and networks and asked several people to join her and cochair this new network. This initial group of national leaders included Michelle Fine, a New York-based critical psychologist and education researcher and a pioneer of critical participatory action research, Jose Calderon a Los Angeles-based sociologist and activist involved with the farmworker, immigrant rights and educational justice movements, and one of us, Mark Warren, a Boston-based sociologist and education researcher who had studied and worked with community and youth organizing groups for many years. Dayna intentionally assembled a group with diverse backgrounds, including our racial identities, and this was important to signal that URBAN would prioritize issues of racial justice and work to create a truly diverse space for activist scholars, compared to the typically white dominated space of the academy. This small group had wide reach through their own networks, and this later brought into URBAN the other of us, Ron Glass, and his 
network in the Center for Collaborative Research for an Equitable California, a University of California system-wide research program initiative, which had been founded in 2009.

\section{The Formation of URBAN}

URBAN formed at a moment of opportunity. While community engaged or activist scholarship has a long tradition, the founders of URBAN believed the field was at a new moment. Years of growing inequality, persistent poverty and racial inequities, increasing environmental challenges and attacks on immigrants demanded a response from academia that was largely missing. The rise of evidence-based practice and big data meant that research and data-based knowledge were more important than ever, yet aggrieved communities typically lacked access to data relevant to advocating for their policy objectives. Meanwhile, a new generation of scholars, often led by scholars of color and women, came to graduate studies because of their deep passion to contribute to social justice, yet found the academy pushed them towards traditional, detached research agendas that seemed irrelevant to the pressing demands of urban communities. Many scholars nevertheless pursued community-engaged research but they did so isolated in their own silos - in their institutions, disciplines, localities or policy areas.

We launched URBAN as a national, interdisciplinary and cross-policy network of scholars and activists. Although we were concerned with combating inequality and oppression in all its forms, we placed a special emphasis on racial equity and combating racism because we believed it was a central form of oppression in urban communities and the one that the academy was often unwilling to address explicitly. We had a number of goals in mind for URBAN. First and foremost, URBAN would help connect activist scholars across their silos and create a space for an exchange of ideas, analyses and best practices. By doing so, it would strengthen the diverse field of community-engaged research and help practitioners advance their practice. In the context of an often hostile academic establishment, URBAN would serve as a place of support and encouragement for community engaged scholars, especially graduate students and early career scholars struggling to find their way. In addition, URBAN would be an advocate for promoting activist scholarship within the academy, demonstrating its critical contributions to knowledge production and action for social change. In this context, we would challenge the hierarchy of knowledge production and power, which places academics and experts above communities struggling for change. We would advocate for institutional change in such forms as revised tenure and promotion policies that reward community engaged scholarship.

These were ambitious goals and, in practice, we ended up focusing on initiatives that URBAN members stepped forward to organize. We evolved a volunteer model with very limited funds and no professional support staff. The positive side of this model is the enthusiasm and passion of those who participated. The downside is the lack of an ability to deploy resources to grow in collectively decided, strategic ways.

This platform or venue proved highly attractive to many people. In fact, we received a very strong response and great interest wherever we took our efforts. We learned, though, that some activist scholars already had a home with which they were satisfied and they tended not to join with URBAN. In fact, Dayna had reached out to a number of people in her networks. Some got involved and some did not. The aim of field building suggests the need to connect these networks, but the more immediate demands of time and limited resources led some people to stay within their worlds. We never imagined nor sought to have URBAN as the umbrella network for an entire field, and we have continued to struggle to see how URBAN can play a role in more thickly connecting existing networks. 
We proceeded to organize ourselves into nodes or chapters in the places we inhabited. We launched local nodes in Boston, New York City, and Los Angeles, and later added nodes in Philadelphia, the Hartford/Springfield area and Denver/Boulder, Colorado. As of this writing, activist scholars in Minneapolis, Salt Lake City, Atlanta and the Bay Area are in discussion about forming nodes. We also created "national" nodes among researchers in education and sociology. Meanwhile, URBAN included networks among urban planners and critical psychologists, and sponsored gatherings and sessions at the Urban Affairs Association meetings, although no formal nodes have yet to be formed in those fields.

URBAN members saw local nodes as places where activist scholars could gather with each other and with community and education activists. The local nodes varied in their activities, depending on the interests of members and leaders. Once again, the volunteer model allowed for a range of types of focus, but all nodes sought to be places for relationship building, sharing of experience, mutual learning, and the fostering of new and deeper forms of collaborative research. The national nodes took advantage of the annual professional meetings in their disciplines as sites to gather activist scholars. URBAN members proposed sessions on activist scholarship for these annual meetings, including mentoring sessions for graduate students and early career scholars.

As the nodes formed, URBAN tried to build connections across silos and enable its members to connect across localities and discipline or policy areas. To facilitate these national, cross-disciplinary connections, a website was created with the support of SAGE Publications, and it continues to serve as a vehicle for communication and sharing of resources, whether through URBAN' biannual newsletter or through contributions from members and nodes. Participants can sign up to URBAN through membership in a node or as an individual.

As URBAN coalesced into a distributed national network, it became evident to URBAN leaders that the differences, challenges and questions emerging from within and among those practicing collaborative research for justice were significant in themselves. These issues needed to be clarified and systematically addressed and our findings shared out through academic publication venues. URBAN could thus play a role at the level of theory and institution building as well as in the organization of the network and improving practice, building linkages, and exploring the possibilities of movement building for educational and social justice.

\section{Gatherings and Publications to Build a Field}

The most active URBAN members across the geographic and disciplinary nodes felt the need to meet face-to-face to work on the often fraught ethical, epistemological, and political issues that were evident in collaborative research for justice. The national leaders sought out funding to support gatherings that would generate both academic publications as well as other forms of knowledge production and dissemination that might have wider reach, such as graphic visualizations and videos. A conference grant from the American Educational Research Association was secured for URBAN's first national convening (Boston, MA), and then grants from the Spencer Foundation and the William T. Grant Foundation supported two additional conferences (Boston, MA and New York, NY). A fourth gathering occurred in Denver in 2018, supported in part by the Ford and Spencer Foundations. Our success in winning these awards from mainstream research organizations and foundations suggests a new openness to collaborative research in the larger world of academia as well as growing evidence of the power and necessity of this kind of research and the benefits of clarification and guidance on foundational issues for this emergent field.

The planning team for the first and second conferences included URBAN national co-chairs Mark Warren and Michelle Fine (CUNY), Ronald Glass, John Diamond (University of Wisconsin Madison), Timothy Eatman (Syracuse University, now Rutgers University - Newark), and Celina Su 
(CUNY) who became a national co-chair when she was appointed to the Marilyn Gittell Chair at the CUNY Graduate Center. For the first conference held at the University of Massachusetts Boston in the spring of 2015, planning team members organized and chaired working groups that met over the course of nearly a year to plan the agenda and draft papers to present. This process brought even more engaged scholars into URBAN and into our dialogical process of grappling with the foundational issues that confronted those in academe and communities who sought to put research to work for justice in the public sphere.

The conferences became places for members both within and outside of nodes to participate, connect, share and learn. The conferences proved exciting and provocative and stimulated more interest and involvement, and some people who attended began to work on forming new nodes. The conferences also enabled participants to move beyond their silos and particular networks and to start to learn about the diversity in this large interdisciplinary and multiissue field and clarify areas of agreement and difference. A fault line opened up at the first conference around the very possibility of situating community engaged scholarship in the academy when the academy itself was founded upon coloniality and upholds settler colonial hegemonic notions of knowledge production, and thus continues to be implicated in the oppression of marginalized communities and the extraction of value from their lands and resources. Some participants rejected the very project of claiming space within academia in favor of supporting work situated in the community, while others saw activist scholarship as a way to open up the possibilities within the contradictory spaces of universities to challenge epistemic injustices and inequitable hierarchies, and to support struggles for social justice. We did not resolve this debate and some working group members and conference participants decided that the intersectional space of URBAN was not a venue for the direction their work was moving in. The working groups engaged with the debates as they unfolded in that first gathering, and then produced a special issue of Urban Education (Warren et al, 2018) that explores these and other contradictions of violence, power, and oppression in the work of community engaged scholarship, while arguing for the ethicality, coherence, rigor, and relevance for policy and practice that the work offers as well.

We also began to forge some common commitments about who can represent the work of activist research and about how it can and should be represented by community members, young people, artists, humanists, and others as well as social scientists, and about the need to include critical education into our analyses of systems of oppression and strategies for our work with communities. We also recognized that URBAN could use its growing voice and organization to act in the face of the urgency of rising attacks. At one of our conferences, we wrote a letter signed by one hundred and fifty URBAN members in support of students at the University of Missouri who were protesting racism on campus at the time. The third conference, held at the CUNY Graduate Center in the spring of 2016, built upon the relationships and shared understandings created at the first two convenings and, in many ways, served as the public launch for the URBAN network with over one hundred participants attending. Celina Su chaired an expanded conference planning team for the third conference that included scholars like Julio Cammarota (Iowa State, now University of New Mexico) and Alvaro Huerta (California State Polytechnic University, Pomona), graduate students and post-docs like Ben Teresa (CUNY), Lindsay Morgia (University of Massachusetts Boston) and Ana Antunes (University of Utah), and artists and activists like Daniel Carillo and Lize Mogel from New York City.

We were surprised at the power of the multi-modal presentations at the conferences and how meaningful attendees found the gatherings. We organized the meetings to give equal voice to established scholars, to early career scholars and to community and educator activists, and we ensured that the group was diverse with very strong participation and leadership from people of 
color. In the second and third gatherings, artists enriched the conversations among engaged scholars, community leaders and activists. With each gathering, we experimented with our own forms of conferencing, dialoguing and engaging one another, and at various moments we incorporated graphic visualization, poetry, dramatizations, role plays, the visual arts, and other activities that were integrated with more traditional academic modes of knowledge production, such as this special issue of $\operatorname{EPAA}$. We believe that the diversity of our modes of reflection and engagement with one another helped us individually and collectively as a network to delve deeply around our values of racial and social justice, which we believe are central to the ethical practice of collaborative research. We believe these modes of knowledge production and dissemination need to be granted more space in the academy as well as in other halls of power and decision making.

By bringing together the intellect with emotion and values and creating multiple forms of analysis and engagement, our gatherings allowed for deep and penetrating conversation, connection and understanding that went beyond traditional discourse at academic or professional meetings. Panelists explored different means of disseminating findings and impacting policy, including storytelling, art and performance, and they explored artistic practices themselves as modes of research and data-gathering. These conversations, which reimagined research, policy and practice, often prompted intellectual and creative breakthroughs and shifts in frameworks, like a panel conversation at our New York gathering on the racial politics of immigration that opened the possibility of an unanticipated alliance among local organizations as well as new conceptual space for imagining movement building. Such moments are rare at academic conferences. Indeed, we learned that to move people into impactful equity-oriented forms of action, community knowledge had to be valued and integrated with the best of social science-based research methods and then fused with forms of discourse that enfold stories, values and emotions. This multifaceted form of engagement is needed to facilitate the kind of deep understandings of wickedly profound issues of social and racial injustice that confront us and to design strategic defenses and imagine transformative possibilities.

To illustrate how we approached engagement in URBAN's gatherings, it is useful to explore Paul Kuttner's (University of Utah) graphic visualizations from our first conference. Paul, in real time, captured the multifaceted presentations of the working groups and the often intense and contentious discussions. The resulting graphics explore themes of how collaborative research for justice is related to advocacy and research rigor, how it must navigate institutional barriers and cobble together supports, and how it can play a powerful role in policy development and change. One of Paul's graphics visualized the presentation and discussion of the ethics working group led by Ron Glass, and later he along with working group members Joyce King and Sheeva Sabati provided a video commentary on the graphic. All the working groups later wrote academic papers on these same themes which then were published together in the special issue of Urban Education mentioned earlier (Warren et al, 2018). At the New York conference, we produced short videos featuring various URBAN affiliated scholars and activists sharing key lessons about turning points in their careers, how they put their research to work for justice, and advice they have for the next generation. Another video produced at the conference featured scholar-activists reflecting on how their work was publicly engaged. These explorations in multi-modal forms of knowledge production and dissemination extended to our strategic planning for how URBAN could facilitate broader field building for collaborative research for justice, a process that Paul Kuttner also captured in a graphic visualization.

These strategic discussions revealed the extent and depth of the hunger for connection among activist scholars who were isolated in their institutions or in smaller towns, and also for guidance and support in their efforts to connect with community- and school-based actors. Early 
career scholars in particular felt themselves to be in especially precarious situations, in departments with senior faculty who do not understand or support activist scholarship, struggling with Institutional Review Board procedures that do not align with collaborative approaches to research, and facing faculty reward structures that do not value the range of products that are produced through community engaged scholarship. Frank discussions also occurred at the gatherings around the tensions that exist in forming truly collaborative and mutual partnerships across the academic/community divide including power hierarchies and the different timelines and demands faced by academics versus community and education activists. These conversations challenged URBAN leadership to seek ways to build an infrastructure that could respond adequately to suture together the growing field into something more like a research based movement for educational and social justice.

\section{Looking Forward}

As URBAN established itself as a valuable network with a broad reach and a committed leadership, it also found an institutional home. In advance of the third conference, URBAN moved to the CUNY Graduate Center under the leadership of Celina Su, who became the coordinating cochair of the network when she assumed the Gittell Chair. Over the past several years, Celina and the URBAN network have been supported by a dedicated post-doctoral fellow, Erika Grajeda. Also important for URBAN was the expressive value of being located at a public university to indicate our commitment to public investment in K-12 and higher education, and the role and responsibility of public universities to support community well-being and social justice.

In the two years following the third conference, URBAN expanded its leadership to include many of the participants who stepped forward during the conference process and in the newly established nodes. In addition to the special issue of Urban Education and the special issue of EPAA of which this reflection is a part, members of the education node edited a special issue of the International Journal of Qualitative Studies in Education. We also successfully transitioned the national leadership as Jose Calderon and Dayna Cunningham stepped down, and Julio Cammarota, Ana Antunes, Paige Bray (University of Hartford), and Tim Eatman became new co-chairs joining Michelle Fine, Celina Su and Mark Warren, who continue to serve. We have a handful of very active nodes and more forming in which people find connection, support, learning and collaboration. We have individuals who also find that URBAN provides a platform to take initiatives that meet their values and interests. For example, a group of sociology node members wrote guidelines for journal publishers to use in evaluating community-based research. In 2018, activist scholars in Denver and Boulder, including Ben Kirschner, Antwan Jefferson, Vanessa Roberts, Blanca Elena Trejo, and their colleagues in the University of Colorado's CU-Engage office formally formed a node and held URBAN's fourth conference with great success. That conference featured collaborative research focused on the housing crisis in urban communities and its intersections with educational inequities as well as on critical youth participatory research. As with prior gatherings, a variety of forms of dissemination of the knowledge generated are being developed. Meanwhile, Chris Benner, Steve McKay, Ron Glass and their activist scholar colleagues at the University of California Santa Cruz have volunteered to hold URBAN's fifth national conference in April 2020.

URBAN now has a broad and deep core of committed leaders who share common values and purpose and are willing to volunteer their precious time to building the network and extending the reach and impact of collaborative research for justice. As the articles in our EPAA special issue detail, intensive research for justice movement building work has been occurring to combat the persistent unemployment for racialized and low-income youth, the over policing of urban youth and

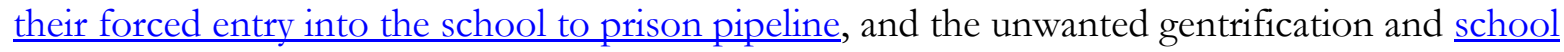


closures damaging too many urban neighborhoods. URBAN networked scholar-activists are making growing connections with community organizers and leaders, artists, and others through the network's geographic and disciplinary nodes and national conferences, and URBAN remains committed to sharing its learnings and engaging the larger world of action research and the academy more broadly through its website and curated publications.

URBAN is now effectively experimenting with a new hybrid model for its network, one that works deeply within communities, widely within disciplines and dynamically across communities and disciplines. Our structure includes (1) deep site/node based research/activism activities, rooted in local issues and struggles, e.g. charter school expansion, immigration rights and education, gentrification and school closings, and teacher development; (2) intense disciplinary commitments in professional associations, e.g. American Educational Research Association, American Sociological Association, and Urban Affairs Association, where URBAN has widened professional conversations about community based research; and (3) cross-city, cross-discipline provocations and discussions focused on the increasingly lively and often fraught research dynamics between universities and communities, social policy and organizing.

URBAN's growth comes at a time of intense political contestation. The Trump presidency has ushered in a reawakened white nationalist movement that threatens immigrants, Muslims, women, people of color and our democracy itself. The Trump, Republican Party, and nationalist movement agendas feature attacks on public education and the public university, broader attacks on public investment of all kinds, deportations of undocumented people, rollbacks of environmental protection, and a return to get-tough criminal justice policies. Community resistance has emerged in response. This new activism comes in the wake of the Black Lives Matter movement, which has brought new leadership to the struggle for racial and social justice, one that is more militant and more directly focused on confronting racism as well as on transforming education.

URBAN's mission to conduct research as part of and in collaboration with social justice movement building could not be timelier or more urgent. Successful movements involve many components, but certainly they are built upon deep relationships, shared value commitments, the combination of emotion and intellect, and strategic action. URBAN creates a vehicle for scholars to participate in the creation of these kinds of movement foundations in collaboration with community activists. We have learned just how rare these venues are and how deep the hunger is for opportunities like URBAN. Activist scholars express through URBAN the critical importance of building a community of engaged scholars as an intellectual project but also a community of shared values where people support each other, work to build and expand the field, and engage with the larger world of academia to realign the scholarly mission in support of movements for social justice.

This kind of work speaks forcefully to the present moment and offers promise for making research matter in confronting and transforming the most intractable issues we face as a society. The conditions that give rise to the inequities discussed in this EPAA special issue - in youth employment, to the criminalization of youth of color and the abusive policing of their communities, to the imposition of market logics to schools to dispossess low-income communities and communities of color from control of their children's intellectual, moral, and social formation - can be effectively resisted when truth is set to work. These cases demonstrate that actionable truth emerges when experiential and other forms of community knowledge are connected to sciencebased research. When knowledge production is integrated with knowledge dissemination by and with community mobilization, aggrieved communities can build political power as they expand their knowledge and understanding of both what stands against them and what they themselves stand on. Even so, the URBAN cases also reveal that there are no guarantees, and that the struggle to claim the democratic promise of our schools and universities is ongoing, multi-sited and multi-leveled. 
New generations of activists and scholars have assumed leadership in communities and the academy who understand what is at stake in the struggle over legitimate forms of knowledge and truth claims. They are committed to the difficult work of cultural and institutional change, of building transformed communities of practice that embody more ethical and more politically effective responses to the crisis in truth that precedes this current post-truth moment. While bullshit (Frankfurt, 2005) infuses the words of the US President and literally commands armed forces, moves global financial markets, risks eco-disaster, and encourages hateful violence against the least advantaged yet greatest number of us - the poor, the disabled, people of color, women, the LGBTQ community, and refugees - we believe even more strongly in the power of truth seeking as a form of organizing for justice.

The discussions and analyses in this EPAA special issue that we have curated emanate from the kind of sustained, long term relationships that have been repeatedly shown to be the foundation of ethical partnerships and crucial for designing and implementing transformational responses (Warren \& Goodman, 2018; Warren \& Mapp, 2011) that can strategically intervene in the variety of forms of slow violence (Nixon, 2013) that persistently undermine the possibility of equitable communities. Collaborative research for justice provides a more robust response on the academy side to the forms of epistemic injustice that have long excluded the ways of knowing of the least advantaged (Fricker, 2009; Newman \& Glass, 2014), precisely those most violently impacted by the bullshit, lies, failed policies, and broken promises of policy makers. As ourselves long-time scholaractivists, we take courage from the growth of networks like URBAN and others whose members believe with us that the time has come to move collaborative research for justice from the margins of the academy to the core of its mission. We hope you will join us in that endeavor, and we believe you too will draw inspiration from the reflections, photos, graphics, and videos shared in this EPAA special issue and learn from others who also are walking this road.

\section{About the Special Issue}

This article is part of a special issue of EPAA, Collaborative Research for Justice and Multi-Issue Movement Building: Challenging Discriminatory Policing, School Closures, and Youth Unemployment that was edited by Ronald David Glass and Mark R. Warren and curated by the Urban Research Based Action Network (URBAN). This special issue reflects the network's commitment to producing and utilizing research for justice that combines rigorous scholarship with the arts to engage both the head and heart so as to deepen and express our social justice values in our scholarship. In addition to the cases highlighted in the title of the special issue, there are also essays that interrogate the limits and possibilities of universities for supporting collaborative research for justice, that explore the role that URBAN has played in fostering the formation of both an academic field as well as experiments in fusing knowledge production with knowledge mobilization and community organizing to build movements for justice, and that argue for multi-modal forms of knowing to build the critical solidarities needed to speak truth to multi-scalar powers at local, national, and global levels. These provocative essays are integrated with graphics that explore themes of how collaborative research for justice is related to advocacy and research rigor, how it must navigate institutional barriers and create institutional supports, and how it can play a powerful role in policy development and change. One graphic on the ethics of collaborative community-based research is also integrated with a video commentary. Additional videos feature scholars and activists sharing key lessons about turning points in their careers, accounts of how they put their research to work for justice, and advice they $\underline{\text { have for the next generation. Another video features scholar-activists reflecting on their experiences }}$ 
as publicly engaged scholars. Taken together, this special issue provides robust guidance for putting truth seeking to work on behalf of and in partnership with the least advantaged communities.

\title{
References
}

Frankfurt, H. (2005). On bullshit. Princeton, NJ: Princeton University Press.

Fricker, M. (2009). Epistemic injustice: Power and the ethics of knowing. New York: Oxford University Press.

Newman, A., \& Glass, R. D. (2014). Comparing ethical and epistemic standards for investigative journalists and equity-oriented collaborative community-based researchers: Why working for a university matters. The Journal of Higher Education, 85(3), 283-311.

Nixon, R. (2013). Slow violence and the environmentalism of the poor. Cambridge: Harvard University Press.

Warren, M. R., Diamond, J., Eatman, T., Fine, M., \& Glass, R. D. (Eds) (2018). Special Issue: Research confronts equity and social justice - Building the emerging field of collaborative, community-engaged education research. Urban Education, 53(4), 439-588.

Warren, M. R., \& Goodman, D. (2018). Lift us up don't push us out! Voices from the front lines of the educational justice movement. Boston, MA: Beacon Press.

Warren, M. R., Mapp, K. L. \& the Community Organizing and School Reform Project (2011). A match on dry grass: Community organizing as a catalyst for school reform. New York: Oxford University Press.

\section{About the Authors/Guest Editors}

\author{
Mark R. Warren \\ University of Massachusetts Boston \\ Mark.Warren@umb.edu \\ Mark R. Warren is Professor of Public Policy and Public Affairs at the University of \\ Massachusetts Boston. Mark is the author of several books on community organizing for racial \\ equity and educational justice, including Lift Us Up Don't Push Us Out! Voices from the Front \\ Lines of the Educational Justice Movement. He is a co-founder and co-chair of the Urban \\ Research Based Action Network (URBAN).

\section{Ronald David Glass} \\ University of California, Santa Cruz \\ rglass@ucsc.edu \\ Ronald David Glass is Professor of Philosophy of Education at the University of California, \\ Santa Cruz, USA, and Director of the Center for Collaborative Research for an Equitable \\ California (CCREC). His recent work focuses on the ethics of research, and the foundations of his \\ philosophy have investigated ideological (trans)formation, education as a practice of freedom, and \\ the role engaged research and public learning processes in struggles for justice.
}

Guest Associate Editors: Lindsay Morgia (University of Massachusetts, Boston) and Ben Teresa (Virginia Commonwealth University) 


\title{
education policy analysis archives
}

\author{
Volume 27 Number $53 \quad$ May 20, $2019 \quad$ ISSN 1068-2341
}

\begin{abstract}
(c)
SOMEREIGHISRESERVED Readers are free to copy, display, and distribute this article, as long as the work is attributed to the author(s) and Education Policy Analysis Archives, it is distributed for noncommercial purposes only, and no alteration or transformation is made in the work. More details of this Creative Commons license are available at http://creativecommons.org/licenses/by-nc-sa/3.0/. All other uses must be approved by the author(s) or EPAA. EPAA is published by the Mary Lou Fulton Institute and Graduate School of Education at Arizona State University Articles are indexed in CIRC (Clasificación Integrada de Revistas Científicas, Spain), DIALNET (Spain), Directory of Open Access Journals, EBSCO Education Research Complete, ERIC, Education Full Text (H.W. Wilson), QUALIS A2 (Brazil), SCImago Journal Rank; SCOPUS, SOCOLAR (China).

Please contribute commentaries at http://epaa.info/wordpress/ and send errata notes to Gustavo E. Fischman fischman@asu.edu

Join EPAA's Facebook community at https://www.facebook.com/EPAAAAPE and Twitter feed@epaa_aape.
\end{abstract}




\section{education policy analysis archives editorial board}

Lead Editor: Audrey Amrein-Beardsley (Arizona State University)

Editor Consultor: Gustavo E. Fischman (Arizona State University)

Associate Editors: David Carlson, Lauren Harris, Eugene Judson, Mirka Koro-Ljungberg, Scott Marley, Molly Ott, Iveta Silova (Arizona State University)

Cristina Alfaro

San Diego State University

Gary Anderson

New York University

Michael W. Apple

University of Wisconsin, Madison

Jeff Bale

University of Toronto, Canada

Aaron Bevanot SUNY Albany

David C. Berliner

Arizona State University

Henry Braun Boston College

\section{Casey Cobb}

University of Connecticut

Arnold Danzig

San Jose State University

Linda Darling-Hammond

Stanford University

Elizabeth H. DeBray

University of Georgia

David E. DeMatthews

University of Texas at Austin

Chad d'Entremont Rennie Center

for Education Research \& Policy

John Diamond

University of Wisconsin, Madison

Matthew Di Carlo

Albert Shanker Institute

Sherman Dorn

Arizona State University

Michael J. Dumas

University of California, Berkeley

Kathy Escamilla

University ofColorado, Boulder

Yariv Feniger Ben-Gurion

University of the Negev

Melissa Lynn Freeman

Adams State College

Rachael Gabriel

University of Connecticut
Amy Garrett Dikkers University

of North Carolina, Wilmington

Gene V Glass

Arizona State University

Ronald Glass University of

California, Santa Cruz

Jacob P. K. Gross

University of Louisville

Eric M. Haas WestEd

Julian Vasquez Heilig California

State University, Sacramento

Kimberly Kappler Hewitt University of North Carolina Greensboro

Aimee Howley Ohio University

Steve Klees University of Maryland

Jaekyung Lee SUNY Buffalo

Jessica Nina Lester

Indiana University

Amanda E. Lewis University of

Illinois, Chicago

Chad R. Lochmiller Indiana

University

Christopher Lubienski Indiana

University

Sarah Lubienski Indiana University

William J. Mathis

University of Colorado, Boulder

Michele S. Moses

University of Colorado, Boulder

Julianne Moss

Deakin University, Australia

Sharon Nichols

University of Texas, San Antonio

Eric Parsons

University of Missouri-Columbia

Amanda U. Potterton

University of Kentucky

Susan L. Robertson

Bristol University
Gloria M. Rodriguez

University of California, Davis

R. Anthony Rolle

University of Houston

A. G. Rud

Washington State University

Patricia Sánchez University of

University of Texas, San Antonio

Janelle Scott University of

California, Berkeley

Jack Schneider University of

Massachusetts Lowell

Noah Sobe Loyola University

Nelly P. Stromquist

University of Maryland

Benjamin Superfine

University of Illinois, Chicago

Adai Tefera

Virginia Commonwealth University

A. Chris Torres

Michigan State University

Tina Trujillo

University of California, Berkeley

Federico R. Waitoller

University of Illinois, Chicago

Larisa Warhol

University of Connecticut

John Weathers University of

Colorado, Colorado Springs

Kevin Welner

University of Colorado, Boulder

Terrence G. Wiley

Center for Applied Linguistics

John Willinsky Stanford University

Jennifer R. Wolgemuth

University of South Florida

Kyo Yamashiro

Claremont Graduate University

Miri Yemini

Tel Aviv University, Israel 


\section{archivos analíticos de políticas educativas consejo editorial}

Editor Consultor: Gustavo E. Fischman (Arizona State University)

Editores Asociados: Armando Alcántara Santuario (Universidad Nacional Autónoma de México), Angelica Buendia, (Metropolitan Autonomous University), Alejandra Falabella (Universidad Alberto Hurtado, Chile), Antonio Luzon, (Universidad de Granada), José Luis Ramírez, (Universidad de Sonora), Paula Razquin (Universidad de San Andrés), Maria Alejandra Tejada-Gómez (Pontificia Universidad Javeriana, Colombia)

Claudio Almonacid

Universidad Metropolitana de

Ciencias de la Educación, Chile

Miguel Ángel Arias Ortega

Universidad Autónoma de la

Ciudad de México

Xavier Besalú Costa

Universitat de Girona, España

Xavier Bonal Sarro Universidad

Autónoma de Barcelona, España

Antonio Bolívar Boitia

Universidad de Granada, España

José Joaquín Brunner Universidad

Diego Portales, Chile

Damián Canales Sánchez

Instituto Nacional para la

Evaluación de la Educación,

México

Gabriela de la Cruz Flores

Universidad Nacional Autónoma de

México

Marco Antonio Delgado Fuentes

Universidad Iberoamericana,

México

Inés Dussel, DIE-CINVESTAV, México

Pedro Flores Crespo Universidad

Iberoamericana, México
Ana María García de Fanelli

Centro de Estudios de Estado y

Sociedad (CEDES) CONICET,

Argentina

Juan Carlos González Faraco

Universidad de Huelva, España

María Clemente Linuesa

Universidad de Salamanca, España

Jaume Martínez Bonafé

Universitat de València, España

Alejandro Márquez Jiménez

Instituto de Investigaciones sobre la

Universidad y la Educación,

UNAM, México

María Guadalupe Olivier Tellez,

Universidad Pedagógica Nacional,

México

Miguel Pereyra Universidad de

Granada, España

Mónica Pini Universidad Nacional de San Martín, Argentina

Omar Orlando Pulido Chaves

Instituto para la Investigación

Educativa y el Desarrollo

Pedagógico (IDEP)

José Ignacio Rivas Flores

Universidad de Málaga, España
Miriam Rodríguez Vargas

Universidad Autónoma de

Tamaulipas, México

José Gregorio Rodríguez

Universidad Nacional de Colombia, Colombia

Mario Rueda Beltrán Instituto de Investigaciones sobre la Universidad y la Educación, UNAM, México

José Luis San Fabián Maroto

Universidad de Oviedo, España

Jurjo Torres Santomé, Universidad de la Coruña, España

Yengny Marisol Silva Laya

Universidad Iberoamericana, México

Ernesto Treviño Ronzón

Universidad Veracruzana, México

Ernesto Treviño Villarreal

Universidad Diego Portales

Santiago, Chile

Antoni Verger Planells

Universidad Autónoma de

Barcelona, España

Catalina Wainerman

Universidad de San Andrés, Argentina

Juan Carlos Yáñez Velazco

Universidad de Colima, México 


\section{arquivos analíticos de políticas educativas conselho editorial}

Editor Consultor: Gustavo E. Fischman (Arizona State University)

Editoras Associadas: Kaizo Iwakami Beltrao, (Brazilian School of Public and Private Management - EBAPE/FGV, Brazil), Geovana Mendonça Lunardi Mendes (Universidade do Estado de Santa Catarina), Gilberto José Miranda, (Universidade Federal de Uberlândia, Brazil), Marcia Pletsch, Sandra Regina Sales (Universidade Federal Rural do Rio de Janeiro)

\author{
Almerindo Afonso \\ Universidade do Minho \\ Portugal \\ Rosanna Maria Barros Sá \\ Universidade do Algarve \\ Portugal \\ Maria Helena Bonilla \\ Universidade Federal da Bahia \\ Brasil \\ Rosa Maria Bueno Fischer \\ Universidade Federal do Rio Grande \\ do Sul, Brasil

\section{Alice Casimiro Lopes \\ Universidade do Estado do Rio de \\ Janeiro, Brasil}

\section{Suzana Feldens Schwertner \\ Centro Universitário Univates \\ Brasil}

Flávia Miller Naethe Motta

Universidade Federal Rural do Rio de Janeiro, Brasil

\author{
Alexandre Fernandez Vaz \\ Universidade Federal de Santa \\ Catarina, Brasil
}

\section{Regina Célia Linhares Hostins \\ Universidade do Vale do Itajaí, Brasil}

\section{Alfredo Macedo Gomes \\ Universidade Federal de Pernambuco \\ Brasil}

Jefferson Mainardes

Universidade Estadual de Ponta

Grossa, Brasil

Jader Janer Moreira Lopes
Universidade Federal Fluminense e
Universidade Federal de Juiz de Fora,
Brasil
Debora Nunes
Universidade Federal do Rio Grande
do Norte, Brasil

Alda Junqueira Marin

Pontifícia Universidade Católica de São Paulo, Brasil

Dalila Andrade Oliveira

Universidade Federal de Minas

Gerais, Brasil
José Augusto Pacheco

Universidade do Minho, Portugal

Jane Paiva

Universidade do Estado do Rio de

Janeiro, Brasil

Paulo Alberto Santos Vieira

Universidade do Estado de Mato

Grosso, Brasil

Fabiany de Cássia Tavares Silva

Universidade Federal do Mato

Grosso do Sul, Brasil

\section{António Teodoro}

Universidade Lusófona

Portugal

\section{Lílian do Valle}

Universidade do Estado do Rio de Janeiro, Brasil

\section{Alfredo Veiga-Neto}

Universidade Federal do Rio Grande do Sul, Brasil 